\title{
Identification of organic compounds in the bottom sediments of Moscow urban rivers
}

\author{
D. Kramer, S. Mulyashov \& I. Tikhonova \\ Faculty of Biotechnology and Industrial Ecology, \\ Mendeleev University of Chemical Technology of Russia, \\ Russian Federation
}

\begin{abstract}
In 2009-2012 we took out a survey of three Moscow small rivers that flow in the industrial zones of Moscow: Nischcenka, Businka and Tarakanovka. One of the goals of our observation was to determine total organic pollution of these rivers and to identify organic compounds that occur there. To achieve our goal we measured parameters such as concentration of petroleum products and extracted organic compounds (EOC) and used such method as IR-spectrometry, HPLC and GC-MS. According to the results of our survey organic pollution of bottom sediments of Moscow urban rivers were caused mostly by petroleum products. Bottom sediments also contain such contaminators as organosilicon compounds, $\mathrm{PAH}$ and phtalates.

Keywords: urban rivers, bottom sediments, petroleum products, organic pollution.
\end{abstract}

\section{Introduction}

Bottom sediments are the most conservative part of the natural water bodies and provide information on pollution and watershed characteristics. Thus, bottom sediments can serve as an indicator to determine the composition, intensity and scale of industrial pollution, as their composition reflects the biogeochemical characteristics of catchment areas [1,2]. Determination of pollutants in the upper $(1 \mathrm{~cm})$ layer serves as, taking into account peculiarities of sedimentation, characteristic of the annual process of accumulation of pollutants [3].

In 2009-2012 we carried out a survey of three Moscow small rivers: Nischcenka, Tarakanovka and Businka. Particular emphasis was given to the 
analysis of sediment contamination, as well as identification of potential contaminants of these rivers.

River Nischcenka is located in the southeast of Moscow, left tributary of the Moskva river, flows in the industrial zone. The river is about $11 \mathrm{~km}$ (partially enclosed in a collector). Basin area is $85.7 \mathrm{~km}^{2}$.

River Tarakanovka is situated in the northwest of Moscow, left tributary of the Moskva River, flows in an industrial zone. Length is $7.8 \mathrm{~km}$ (most lies in the collector). The basin area is $18.3 \mathrm{~km}^{2}$. In the $1950-1960$ s the river was almost completely removed to the collector.

River Businka is located in the north of Moscow and Moscow region. The total length of the river is about $4.5 \mathrm{~km}, 1.4 \mathrm{~km}$ of which is in Moscow in the industrial area (part of the river lies in the collector).

In this work we measured total organic pollution of these rivers using such parameters as EOC and concentration of petroleum products and also tried to identify classes and individual representatives of organic pollutants that occur there.

\section{Methodology and field observations}

\subsection{Field observations}

First part of our work was to observe the visual condition of rivers with photographing the area. Our goal was to make description of the coast, vegetation description and to identify possible sources of pollutants in the rivers.

Field observation of all 3 rivers showed that they are all highly influenced by human activity with riverbeds partly degraded and riversides full of anthropogenic trash.

\subsection{Sampling operations}

On the basis of the results of our field observation we chose 9 profiles (sampling points) on each river. In each profile we took water sample and bottom sediment sample. Bottom sediment sample was taken from upper layer $(0-5 \mathrm{~cm})$. All samples were dried to air-dry state and sifted through a $0.1 \mathrm{~mm}$ sieve.

\subsection{Analyzing procedures}

Content of EOC was measured gravimetrically. The analytical procedure for determining EOC concentration as follows: $10 \mathrm{~g}$ of sediment sample was dissolved in $50 \mathrm{ml}$ of methylene chloride $\left(\mathrm{CH}_{2} \mathrm{Cl}_{2}\right)$. Extraction process was carried out in ultrasonic bath for 15 minutes. The extract then was filtered in a chemical glass and solvent was puffed by air flow from special gravimetrical beaker. The content of EOC was determined as a gap between clean beaker and beaker with dry extract. Petroleum products (PP) concentrations in bottom sediment samples were determined by IR-spectrometry.

Upon the results of analyses for EOC and petroleum products content we chose several samples for identification of organic compounds. We used high 
EOC content and the largest differences between EOC and petroleum products contents as selection criteria. To identify organic compounds we used such methods as IR-spectrometry, HPLC and GC-MS.

Before applying these methods we used special sample preparation: sample solution in $\mathrm{CH}_{2} \mathrm{Cl}_{2}$ was inserted to sodium sulfate and then consequentially eluted through column with activated silicagel with 4 different eluents, including hexane, mixture of hexane and benzene (1:1), benzene and mixture of benzene and methanol (1:1). The volume of each eluent was $60 \mathrm{ml}$. The order of eluents was due to increase of their polarity.

To apply IR-spectrometry we insert eluates in a form of thin film on $\mathrm{KBr}$ glass and analyzed on FTIR-spectrometer FSM-1201 with the resolution of spectrum $1 \mathrm{~cm}^{-1}$.

Identification of organic compounds by HPLC was performed on HPLC "Stayer" with fluorimetric detection and C-18 silicagel column Luma 3u C-18, 3 $\mu \mathrm{m}, 150 \times 3.0 \mathrm{~mm}$. Prior to analysis we spiked several PAH standards and determined their relative to anthracene retention times. The interpretation of received chromatograms was made on the basis of relative retention times and literature data [4].

For GC-MS analyzes we used GC "Crystall 5002" with quadrupole massdetector DSQ II of Thermo Scientific production and capillary column BPX - 5 (5\% phenyl, 95\% methyl polysilylphenylensiloxane), length $60 \mathrm{~m}$, diameter 0.25 $\mathrm{mm}$, film thickness $0.25 \mathrm{~mm}$. Helium was used as a gas carrier, $160 \mathrm{kPa}, 1.5$ $\mathrm{ml} / \mathrm{min}$. Injection volume $-0.5 \mu \mathrm{l}$, split $1 / 2-1 / 4$. Temperature of evaporator was $295^{\circ} \mathrm{C}$, temperature program for analyzes was as follows: $80^{\circ} \mathrm{C}$ held $2 \mathrm{~min}$, then increased at a rate of $12 \circ / \mathrm{min}$ to $290^{\circ} \mathrm{C}$. Temperature of GC-MS interface was $265^{\circ} \mathrm{C}$, ionization by electron impact of $70 \mathrm{eV}$. Chromatograms were registered by full ion current 35-650 m/z, time of analyzes was 35 minutes. As spectral databases NIST and WILLEY libraries were used.

\section{Results and discussion}

\subsection{Extracted organic compounds (EOC) and petroleum products (PP)}

There are no regulations for EOC concentrations either in bottom sediments or in soil so this analysis was done to determine total content of organic matter in bottom sediments and the difference between it and concentration of petroleum products.

To estimate the contamination by PP we used concentration of PP in soil that is considered acceptable for Moscow region - $1000 \mathrm{mg} / \mathrm{kg}$.

The results of EOC and PP analyses are presented in table 1.

The results of analyses for PP in Moscow small rivers showed high intensity of entry of these substances to the rivers and allowed us to identify the sources of pollution.

The results of analysis on the EOC for all rivers show a symbatical ratio between the EOC content and petroleum product concentrations, which means that the organic pollution in rivers is mainly caused by petroleum products. 
Table 1: Concentration $(\mathrm{mg} / \mathrm{kg})$ of EOC and PP in bottom sediments of Moscow small rivers.

\begin{tabular}{|l|r|r|r|r|r|r|r|r|r|r|}
\hline & \multicolumn{10}{|c|}{ № of sampling point } \\
\hline & 1 & 2 & 3 & 4 & 5 & 6 & 7 & 8 & 9 \\
\hline & \multicolumn{8}{|c|}{ River Nischcenka } \\
\hline EOC & 1700.0 & 1030.0 & 1320.0 & 1820.0 & 1510.0 & 2300.0 & 6165.0 & 13500.0 & 11980.0 \\
\hline PP & 728.3 & 658.4 & 608.6 & 704.3 & 577.5 & $\mathbf{1 2 9 1 . 8}$ & $\mathbf{5 2 9 6 . 8}$ & $\mathbf{5 0 1 4 . 1}$ & $\mathbf{7 3 5 0}$ \\
\hline & \multicolumn{8}{|c|}{ River Tarakanovka } \\
\hline EOC & 7100.0 & 2020.0 & 1650.0 & 3100.0 & 2030.0 & 1330.0 & 140.0 & 1060.0 & 890.0 \\
\hline PP & $\mathbf{6 8 3 5 . 5}$ & 646.0 & 515.2 & 918.0 & 702.0 & 579.8 & 264.5 & 632.5 & 537.6 \\
\hline & & \multicolumn{8}{|c|}{ River Businka } & \\
\hline EOC & 3550.0 & 5200.0 & 2270.0 & 8000.0 & 7320.0 & 2070.0 & 2860.0 & 5320.0 & 11670.0 \\
\hline PP & 768.0 & $\mathbf{3 4 7 0 . 6}$ & 871.8 & $\mathbf{4 5 0 2 . 6}$ & $\mathbf{3 1 1 1 . 1}$ & 646.8 & $\mathbf{1 2 8 0 . 7}$ & $\mathbf{1 9 2 8 . 2}$ & $\mathbf{5 4 1 4 . 4}$ \\
\hline
\end{tabular}

Note: concentrations that exceed acceptable level for PP are bold.

\subsection{IR-spectrometry data}

After EOC analyzes we chose several samples for more particular research on organic contamination of bottom sediments. For IR-spectrometry we used samples Businka 9 and Tarakanovka 4.

On figure 1 you can see IR-spectrums of these samples with the eluent being mixture of hexane and benzene (1:1).

The IR-spectrum of a sample of bottom sediments of the Businka river has low-intensity stretching vibrations of the protons, similar to fluctuations in alcoholic hydroxyl groups in range of $3500-3100 \mathrm{~cm}^{-1}$. In the range of 3100$3020 \mathrm{~cm}^{-1}$ there is an undifferentiated signal from stretching vibrations of protons in the carbon-carbon double bond. The clear position of the maximum of these oscillations is revealed by analysis of the spectral curve of the first derivative. In the range of $3000-2800 \mathrm{~cm}^{-1}$ intense proton stretching vibrations of methyl and methylene groups are observed. They correspond to the deformation vibrations of $1470-1370 \mathrm{~cm}^{-1}$. In the range of $1280-800 \mathrm{~cm}^{-1}$ group of bands that characterize the stretching and bending vibrations in silicone compounds is presented.

IR-spectrum of the sample of bottom sediments of the river Tarakanovka belongs to aliphatic hydrocarbon with a molecular weight greater than 200, as evidenced by the band at $720 \mathrm{~cm}^{-1}$, belonging to the deformation vibrations of long hydrocarbon chains. 

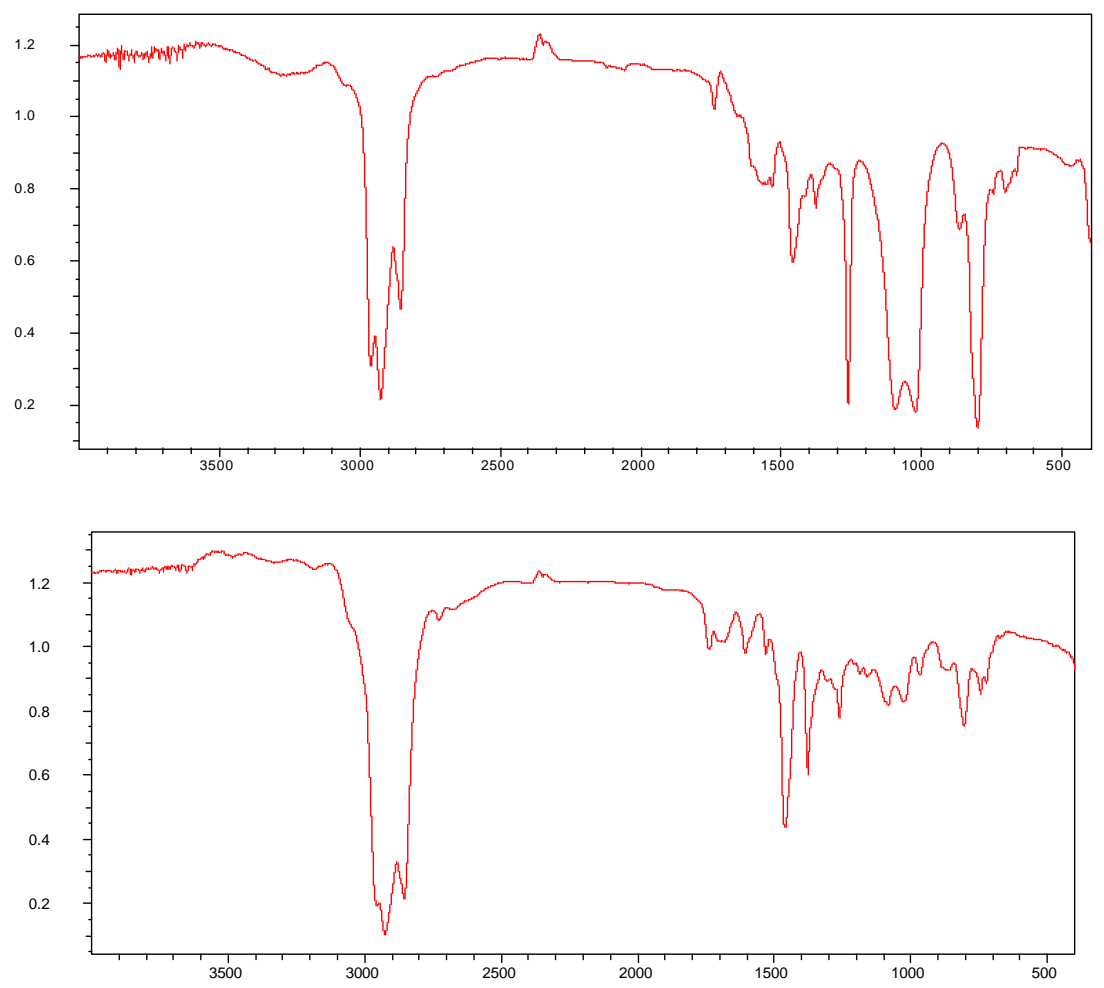

Figure 1: IR-spectrum of bottom sediment samples Businka 9 and Tarakanovka 4. Eluent: mixture of hexane and benzene (1:1).

Spectral analysis of the samples suggest that they are mixtures of saturates, unsaturated hydrocarbons such as mineral oils and silicone oils in various ratios - from the dominance of the mineral part to the dominance of silicone part. In the spectra of samples of sediment of the river Busnika with eluates being hexane:benzene and benzene dominates silicone part, whereas in similar fractions of river Tarakanovka sediment samples - mineral.

\subsection{HPLC analyzes}

The goal was to identify PAH that occur in bottom sediments of Moscow small rivers. HPLC analyzes were done for samples Nischcenka 1, Businka 9 and Tarakanovka 4. Chromatograms of these samples using different eluents are presented on figures 2 and 3. In table 2 you can see main PAH in all eluates of chosen samples. All eluates were diluted by 30 times. 
Table 2: $\quad$ Main PAH in bottom sediments of Moscow urban rivers.

\begin{tabular}{|c|c|c|c|}
\hline PAH & Peak № & $\begin{array}{l}\text { Retention time, } \\
\text { min }\end{array}$ & $\begin{array}{c}\text { Peak area, } \\
\mathrm{mV}^{*} \text { sec }\end{array}$ \\
\hline \multicolumn{4}{|c|}{ Businka 9} \\
\hline \multicolumn{4}{|c|}{ eluent: hexane:benzene $=1: 1$} \\
\hline Benzo(a)pyrene & 21 & 16.34 & 10065.00 \\
\hline Dibenz(a,h)anthracene & 24 & 19.94 & 10297.55 \\
\hline \multicolumn{4}{|c|}{ eluent: benzene } \\
\hline Fluorene & 5 & 6.806 & 3794.72 \\
\hline \multicolumn{4}{|c|}{ eluent: benzene:methanol = 1:1 } \\
\hline Fluoranthene or Pyrene & 16 & 10.47 & 6867.52 \\
\hline Dibenz(a,h)anthracene & 25 & 20.45 & 27973.41 \\
\hline \multicolumn{4}{|c|}{ Nischcenka 1} \\
\hline \multicolumn{4}{|c|}{ eluent: hexane:benzene $=1: 1$} \\
\hline Benzo(a)pyrene & 16 & 15.98 & 3619.36 \\
\hline Dibenz(a,h)anthracene & 18 & 19.46 & 4164.18 \\
\hline \multicolumn{4}{|c|}{ eluent: benzene } \\
\hline Fluorene & 8 & 6.678 & 5726.47 \\
\hline \multicolumn{4}{|c|}{ eluent: benzene:methanol = $1: 1$} \\
\hline Anthracene & 12 & 8.817 & 12763.27 \\
\hline Pyrene & 13 & 10.24 & 12960.31 \\
\hline Dibenz(a,h)anthracene & 21 & 19.94 & 24994.32 \\
\hline \multicolumn{4}{|c|}{ 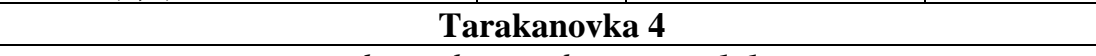 } \\
\hline \multicolumn{4}{|c|}{ eluent: hexane:benzene $=1: 1$} \\
\hline Benzo(a)pyrene & 14 & 15.77 & 6570.49 \\
\hline \multicolumn{4}{|c|}{ eluent: benzene } \\
\hline Fluorene & 14 & 6.511 & 26209.44 \\
\hline Dibenz(a,h)anthracene & 23 & 19.42 & 17168.41 \\
\hline \multicolumn{4}{|c|}{ eluent: benzene:methanol = 1:1 } \\
\hline Phenanthrene & 15 & 7.594 & 19037.20 \\
\hline Anthracene & 16 & 8.519 & 31590.52 \\
\hline Fluoranthene & 17 & 9.87 & 18107.52 \\
\hline
\end{tabular}

From table 2 you can see that in the eluate hexane: benzene most represented are benzo (a) pyrene and dibenz ( $a, h)$ anthracene, fluorene is the most dominant $\mathrm{PAH}$ in eluate benzene, and the eluate benzene: methanol has significant amount of anthracene and its derivatives. 


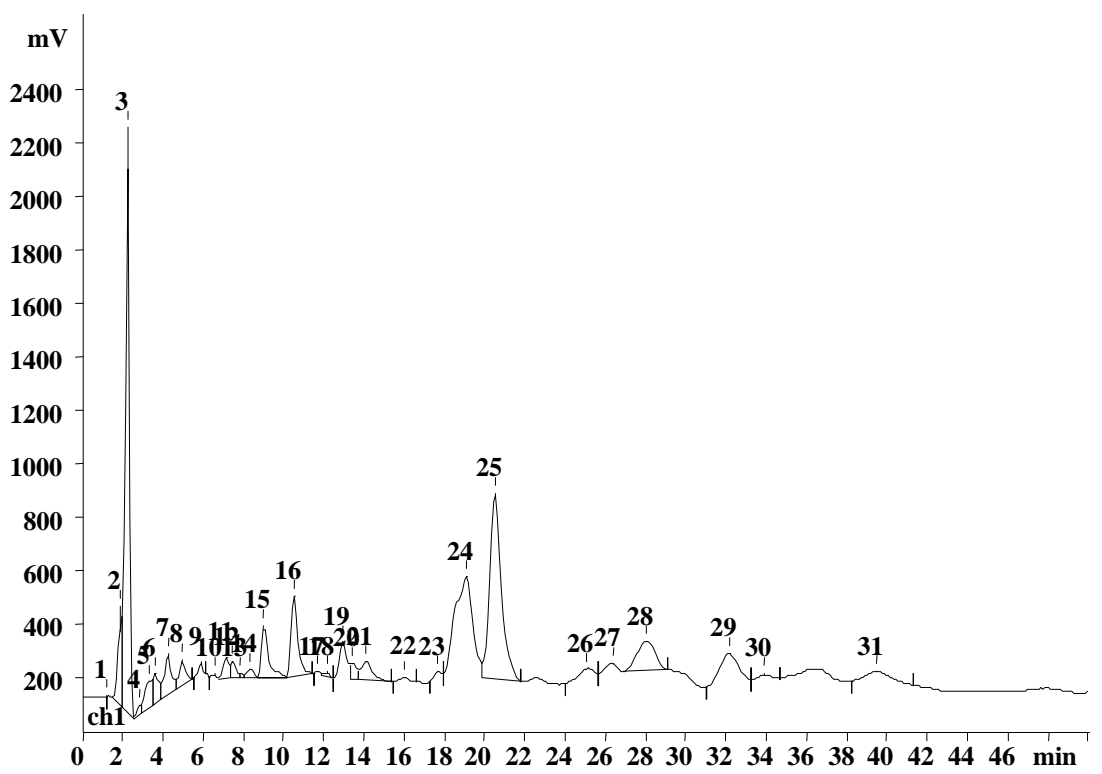

Figure 2: Chromatogram of sample Businka 9 (eluent: benzene: methanol = $1: 1)$.

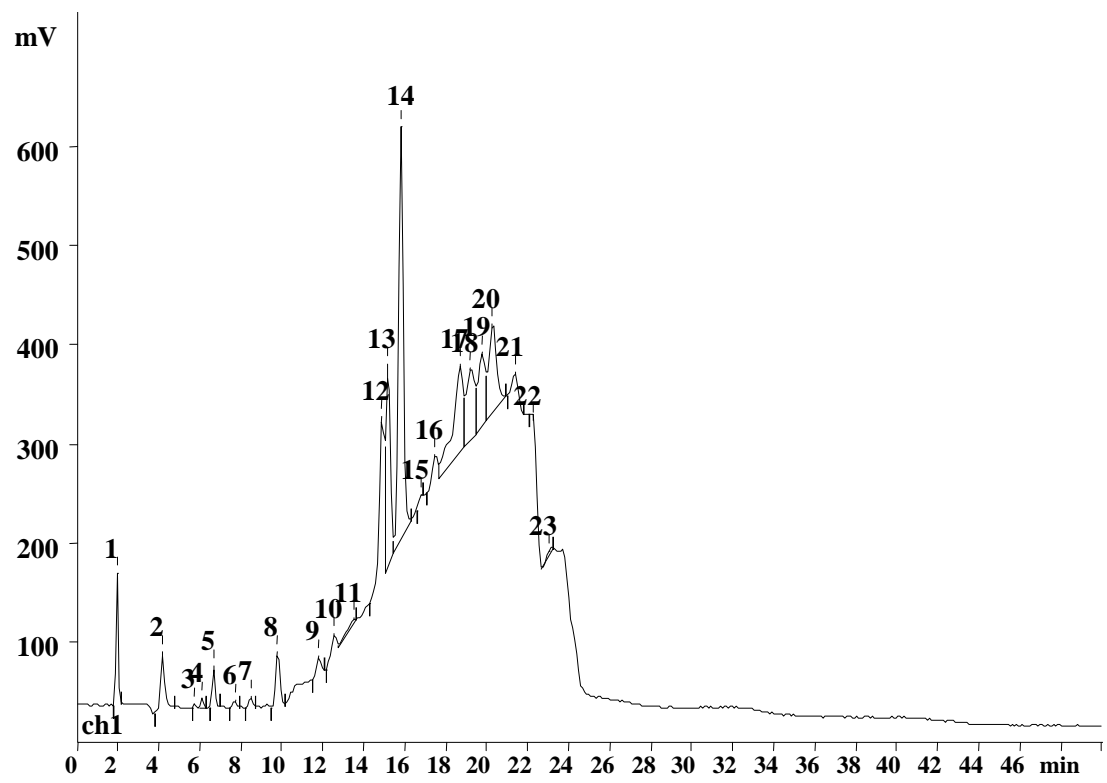

Figure 3: Chromatogram of sample Tarakanovka 4 (eluent: hexane:benzene = $1: 1)$. 


\subsection{GC-MS analyzes}

The goal was to find organic contaminants besides PAH and also to confirm data from IR-spectrometry. GC-MS analyzes was done to samples Businka 9 and Nischcenka 1.

Chromatograms are shown on fig. 4 and 5. In table 3 you can see their interpretation with organic substances occurring in bottom sediments of Moscow small rivers.

Table 3: $\quad$ Organic substances in bottom sediments of Moscow small rivers.

\begin{tabular}{|c|c|c|c|}
\hline Substance & $\begin{array}{c}\text { Peak } \\
\text { № }\end{array}$ & $\begin{array}{l}\text { Retention time, } \\
\text { min }\end{array}$ & $\%$ area \\
\hline \multicolumn{4}{|c|}{ Businka 9} \\
\hline \multicolumn{4}{|c|}{ eluent: hexane:benzene $=1: 1$} \\
\hline pentadecane & 1 & 13.28 & 10.45 \\
\hline dibutylphthalate & 8 & 19.63 & 10.25 \\
\hline 2-(octyloxy)nitrobenzene & 9 & 20.20 & 28.51 \\
\hline $\begin{array}{l}\text { dioctyl ether of hexandioic } \\
\text { acid }\end{array}$ & 10 & 23.04 & 17.85 \\
\hline bis-(2-ethylgexyl)-terephtalate & 11 & 24.97 & 8.15 \\
\hline \multicolumn{4}{|c|}{ eluent: benzene } \\
\hline pentadecane & 4 & 14.68 & 10.44 \\
\hline hexadecane & 5 & 15.74 & 11.24 \\
\hline docosane & 6 & 16.78 & 13.42 \\
\hline 2-(octyloxy)nitrobenzene & 8 & 20.30 & 17.93 \\
\hline $\begin{array}{l}\text { dioctyl ether of hexandioic } \\
\text { acid }\end{array}$ & 9 & 23.20 & 18.45 \\
\hline bis-(2-ethylgexyl)-phtalate & 10 & 25.10 & 7.88 \\
\hline \multicolumn{4}{|c|}{ Nischcenka 1} \\
\hline \multicolumn{4}{|c|}{ eluent: hexane:benzene $=1: 1$} \\
\hline butyl octylphthalate & 4 & 19.70 & 9.56 \\
\hline 2-(octyloxy)nitrobenzene & 5 & 20.15 & 43.85 \\
\hline dioctyladipinate & 6 & 23.16 & 17.46 \\
\hline diisooctylphtalate & 7 & 25.04 & 14.59 \\
\hline
\end{tabular}

Probability of coincidence of mass spectrums obtained by analysis presented in the table with the spectra database was $90 \%$ or more.

From table 3 you can see that besides of PAH bottom sediments of Moscow small rivers contain such organic contaminants as hydrocarbons (it is also confirmed by IR-spectrometry), adipinates and phthalates, ethers and 2(octyloxy)nitrobenzene with the last one having biggest impact. 


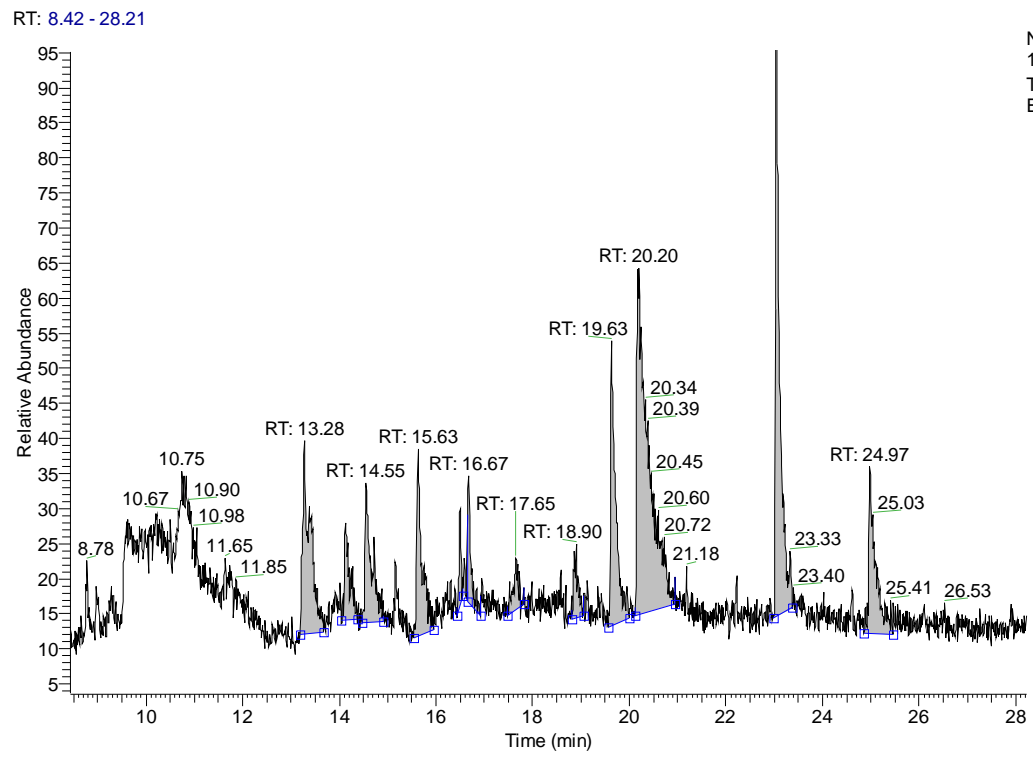

Figure 4: Chromatogram of sample Businka 9 (eluent: hexane:benzene = $1: 1)$.

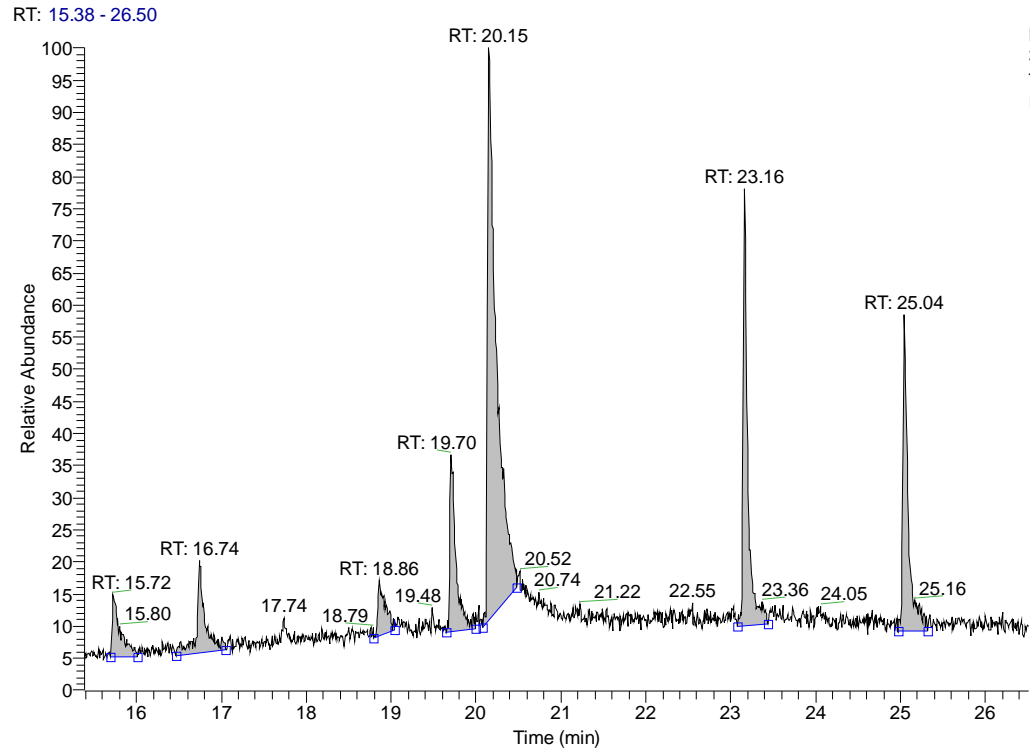

Figure 5: Chromatogram of sample Nischcenka 1 (eluent: hexane:benzene = $1: 1)$. 


\section{Conclusion}

In this work we observed bottom sediments of three Moscow urban rivers: Nischcenka, Businka and Tarakanovka. All these rivers are situated in industrial zones and are exposed with strong anthropogenic impact like wastewaters from nearby facilities or illegal dumps on rivers' banks.

Compounds, identified by GC-MS, such as ethers, phthalates and adipinates, are plasticizers used in production of polymer materials such as PVC. They can be found in bottom sediments due to their wash out of garbage that occur in riverbed or on riverbanks. Silicone compounds found in bottom sediments of river Businka are also of anthropogenic origin. Their presence is due to closeness of poorly organized dumping of solid waste. In bottom sediments samples of other rivers these substances were not found.

We also identified low molecular weight 3-4-ring PAHs such as fluorine, anthracene, phenanthrene, fluoranthene and pyrene; high molecular weight 5-6ring PAHs - dibenz(a,h)anthracene and benzo(a)pyrene. $\mathrm{PAH}$ composition demonstrates their predominantly man-made origin.

The results of our investigation show that bottom sediments of these rivers are highly contaminated by organic substances but to know the precise degree of anthropogenic impact we would have to observe relatively clean and background rivers that flew out of industrial zones for example in city parks where such impact is minimal or absent.

\section{References}

[1] Papina, T.S., Transport i osobennosti raspredeleniya tyazhelyh metallov v ryadu "voda-vzveshennie veshchestva-donnie otlozheniya" rechnich ecosystem (Transportation and distribution characteristics of heavy metals in a range "water-suspended matter-sediments" of river ecosystems), GPNTB SO RAS, Novosibirsk, 2001.

[2] Yanin, E.P., Technogennie geohimicheskie assotsiatsii v donnyh otlozheniyah malyh rek (sostav, osobennosti, metody otsenki) (Technogenic geochemical associations in sediments of small rivers (the composition, characteristics, assessment methods)), IMGRE, Moscow, 2002.

[3] Pateev, M.R., Mezhphaznyi i transgranichnyi perenos tyazhelyh metallov v pribrezhnyh i ustievyh zonah yuzhnyh morei Rossii (Interphase and transboundary transport of heavy metals in coastal and estuarine areas of the southern seas of Russia), Dissertation, Russian University of Fishery and Oceanography, 2009.

[4] Soniassy, R., Sandra P. and Schlett C., Water analyzes. Organic micropollutants, Hewlett-Packard Company, 1994. 